\title{
Response of Cowpea Genotypes to Drought Stress in Uganda
}

\author{
Saul Eric Mwale ${ }^{1,2}{ }^{*}$, Mildred Ochwo-Ssemakula ${ }^{1}$, Kassim Sadik ${ }^{3}$, Esther Achola1, Valentor Okul ${ }^{1}$, \\ Paul Gibson', Richard Edema1, Wales Singini'2, Patrick Rubaihayo ${ }^{1}$
}

\author{
${ }^{1}$ School of Agricultural Sciences, Makerere University, Kampala, Uganda \\ ${ }^{2}$ Biological Sciences Department, Mzuzu University, Mzuzu, Malawi \\ ${ }^{3}$ National Agricultural Research Organization, Arua, Uganda \\ Email: ^saul.mwale@gmail.com, mknossemakula@caes.mak.ac.ug, sdkassim@gmail.com, esterjocelyn @gmail.com, \\ valentorokul<valvineraks@yahoo.com,pgibson@siu.edu, redema12@yahoo.com,walessingini@gmail.com, \\ prubaihayo@gmail.com
}

\begin{abstract}
How to cite this paper: Mwale, S.E., Ochwo-Ssemakula, M., Sadik, K., Achola, E., Okul, V., Gibson, P., Edema, R., Singini, W. and Rubaihayo, P. (2017) Response of Cowpea Genotypes to Drought Stress in Uganda. American Journal of Plant Sciences, 8 , 720-733.

https://doi.org/10.4236/ajps.2017.84050
\end{abstract}

Received: November 17, 2016

Accepted: March 17, 2017

Published: March 20, 2017

Copyright $\odot 2017$ by authors and Scientific Research Publishing Inc. This work is licensed under the Creative Commons Attribution International License (CC BY 4.0).

http://creativecommons.org/licenses/by/4.0/

\begin{abstract}
Moisture stress is a challenge to cowpea production in the drought prone areas of eastern and north eastern Uganda, with yield losses of up to $50 \%$ reported. Genotypes grown by farmers are not drought tolerant. This study was therefore, undertaken at Makerere University Agricultural Research Institute Kabanyolo to identify cowpea genotypes tolerant to drought. Thirty cowpea accessions comprising of Ugandan landraces and released varieties, Brazilian lines, Makerere University breeding lines, elite IITA germplasm and seven IITA drought tolerant lines as checks were screened for drought tolerance at vegetative and reproductive stages. The experiment was designed as a $2 \times 37$ factorial and laid out in a split-plot arrangement, 37 genotypes of cowpea at two soil moisture stress levels (T1, no stress and T2, severe stress) with all factorial combinations replicated two times in a screen house. The genotypes showed considerable variability in tolerance to drought. Genotypes were significantly different for chlorophyll content $(P \leq 0.01)$, efficiency of photosystem II $(\mathrm{P} \leq 0.05)$, non-photochemical quenching $(\mathrm{P} \leq 0.05)$, recovery $(\mathrm{P} \leq$ $0.01)$, delayed leaf senescence $(P \leq 0.01)$, grain yield $(P \leq 0.01)$, 100 seed weight $(P \leq 0.05)$, number of pods per plant and number of seeds per pod ( $P$ $\leq 0.001)$. There was a highly significant positive correlation between chlorophyll content and efficiency of photosystem II $(r=0.75, \mathrm{P} \leq 0.001)$ implying that chlorophyll content and efficiency of photosystem II could be used as efficient reference indicators in the selection of drought tolerant genotypes. Genotypes SECOW 5T, SECOW 3B, SECOW 4W, WC 30 and MU 24 C gave relatively high yields under stress and no stress conditions, maintained above mean chlorophyll content, efficiency of photosystem II and had good recovery scores from stress and thus were tolerant to drought stress induced at both
\end{abstract}


vegetative and reproductive stages.

\section{Keywords}

Drought Tolerance, Moisture Stress, Non-Photochemical Quenching, Split Plot

\section{Introduction}

Cowpea is one of the most important food legumes in the drier regions of the tropics and sub-tropics where drought is a major production constraint due to low and erratic rainfall [1]. It provides a cheap source of protein, vitamins and carbohydrates to small scale farmers in East Africa [2]. In Uganda, cowpea is the fourth most widely grown legume crop after common bean, groundnut and soy bean. The crop is intensively cultivated in the northern and eastern regions of Uganda [3] such that it provides an estimated $60 \%$ of the protein required by the population in these regions [4]. Despite its widespread cultivation in Uganda, the yields of cowpea in farmers' fields are still very low averaging $300-500 \mathrm{~kg} \cdot \mathrm{ha}^{-1}$ against a yield potential of 1500 to $3000 \mathrm{~kg} \cdot \mathrm{ha}^{-1}$ [5]. The low yields have been attributed to a number of biotic and abiotic stresses, low yielding local varieties, seed scarcity and poor soils [6]. Although cowpea is considered as being more drought tolerant than many other crops, its productivity is negatively affected by prolonged droughts and high temperatures [7] which are currently attributed to the effects of climate change. Climate models have predicted increased severity and frequency of droughts in Sub-Saharan Africa [8]. Development and adoption of drought tolerant varieties is one of the options to cope with the changing climate.

Cowpea is sensitive to soil moisture stress during the vegetative and reproductive growth stages [9]. Drought stress during flowering and pod filling impacts negatively on flower development, pollination, pod setting and grain filling leading to reduced number of pods per plant, reduced seed weight and low seed yield [10]. Plants respond and adapt to drought stress through the induction of various morphological and physiological responses [11]. Screening cowpea for tolerance to drought at either vegetative or reproductive stages elsewhere has focused mainly on morphological, biochemical, physiological and yield related indicators [12] [13] [14] [15] [16]. However, in Uganda such studies have not been reported, considering the multiplicity of factors involved in drought tolerance, much more robust screening techniques to characterize drought tolerance are needed. The study therefore sought to identify candidate drought tolerant lines from Uganda that can be used for future breeding applications using physiological and agro-morphological indicators.

\section{Materials and Methods}

\subsection{Genetic Materials}

Thirty medium maturing cowpea genotypes consisting of landraces from north- 
ern, west central and eastern regions of Uganda, varieties released by the $\mathrm{Na}$ tional Semi-Arid Resources Research Institute (NaSARRI), Brazilian lines, and Makerere University breeding lines were studied at vegetative and reproductive stages. The thirty medium maturing cowpea genotypes were selected based on their yield potential and disease resistance qualities. Seven drought tolerant genotypes from IITA-Kano, Nigeria, were used as checks.

\subsection{Study Area}

The study was conducted between May and December 2015 in a water proof screen house at the Makerere University Agricultural Research Institute-Kabanyolo (MUARIK), Uganda. MUARIK is located at an altitude of 1217 meters above sea level on coordinates $0.16^{\circ} 24^{\prime} 16 \mathrm{~N}$ and $32.5^{\circ} 27^{\prime} 34 \mathrm{E}$, approximately $19 \mathrm{~km}$ in the northeast of Kampala at Kabanyolo in Lake Victoria Crescent [17]. MUARIK has deep ferrallitic soils with $\mathrm{pH}$ range of 5.2 to 6.0. Average temperature during experiment ranged from $25^{\circ} \mathrm{C}-31^{\circ} \mathrm{C}$ while relative humidity ranged from $71 \%$ $90 \%$. The rainfall pattern of MUARIK is bimodal, with an annual average of $1160 \mathrm{~mm}$, with the first rains from March to May, while the second rains are from September to November.

\subsection{Experimental Design}

The experiments were laid out in a randomized complete block design in a split plot arrangement with two replications, two watering regimes as main plots and the test genotypes as subplots. The two water regimes were no stress (pot capacity-50\% maximum water capacity) and severe stress. Eight seeds per each of the 30 cowpea genotypes and 7 drought tolerant checks were planted in the screen house in 10 litre-plastic pot perforated at the base and filled with $10 \mathrm{~kg}$ top soil and later thinned to 4 seeds per pot 8 Days after planting (DAP). The soil used was composed of $66 \%$ sand, $16 \%$ clay, $18 \%$ silt, $0.15 \%$ total nitrogen, 0.53 Cmoles/kg of potassium and 4.24 parts per million (ppm) of phosphorus. NPK fertilizer was applied to soil at the rate of $6 \mathrm{~g} /$ pot, based on soil analysis in order to provide the recommended nutrient requirement for cowpea [18]. The NPK fertilizer was applied to each pot by incorporating it into the soil at planting to remove nutrient deficiency as a limiting factor [18].

\subsection{Treatments}

Water stress treatment at vegetative stage was imposed after 10 - 14 days of initial growth of the plants. The initial soil moisture level for the two treatments was maintained at field capacity (50\% maximum water capacity). Plants in the well-watered treatment (no stress) were maintained at field capacity. A soil moisture meter (MO750 manufactured by Extech Instruments, USA) was used to determine the moisture level in the soil. Plants undergoing a severe stress did not receive water after the initial establishment for 30 days' interval [9] [19]. After 30 days of induced drought stress, watering was resumed. The presence or absence of new growth and whether the growth is from the apical or basal me- 
ristem and recovery was recorded.

Water stress treatment at reproductive stage was imposed after the emergence of flower buds for of each of the genotype in a plot [20]. The drought stress treatment did not receive water for 20 days [21] after stress induction while the non-stress treatment received water twice a week until physiological maturity. After the elapse of the 20 days of drought stress induction, the drought stressed plants received water twice a week up to physiological maturity.

\subsection{Data Collection}

Data was collected on the following growth parameters on individual plant basis in line with the international plant genetic resources cowpea descriptors; wilting, delayed leaf senescence. Stem greenness was scored on a scale of 0 to 5 , with 0 being completely yellow and 5 being completely green [22]. Wilting was scored using both the IBPGR (IB) [23] and [24] scales: total number of leaves per plant; number of leaves showing wilting signs per plant. Wilting was calculated weekly, from the first week to the final week of stress, as the ratio between leaves showing wilting signs and the total number of leaves per plant. Stem greenness and regrowth was scored as recovery parameters, after the two weeks of re-watering. Stem greenness was scored using a scale of $1-5$, where 1 was yellow and 5 was completely green. Regrowth (recovery) was scored using three categories: i.e. 1 with no re-growth; 3 with regrowth from auxiliary buds; and 5 with re-growth from the apical meristems [25].

Chlorophyll content, efficiency of photosystem II and non-photochemical quenching were measured from 10:00 am to $12: 00 \mathrm{pm}$ in the middle three leaflet of the trifoliate leaf from the plant base, which were mature but not senescent leaves using Photosynq device [26] (TerAvest D, May 2015, Photosynq coordinator personal communication). At maturity, the plants were harvested to determine yield components (number of pods per plant, number of seeds per pod, 100 seed weight, and seed yield per plant).

\subsection{Data Analysis}

Data was analyzed using Analysis of Variance with a split plot model in GENSTAT 12 to determine the significance of water regime, genotypes \& genotypes by water regimes on yield \& yield component parameters. The Linear Mathematical Model for Split plot experimental Design used was:

$$
\mathrm{X}_{\mathrm{ijk}}=\mathrm{Y} \cdots+\mathrm{M}_{\mathrm{i}}+\mathrm{B}_{\mathrm{j}}+\mathrm{d}_{\mathrm{ij}}+\mathrm{S}_{\mathrm{k}}+(\mathrm{MS}) \mathrm{jk}+\mathrm{e}_{\mathrm{ijk}},
$$

where $\mathrm{X}_{\mathrm{ijk}}=$ mean observations, $\mathrm{Y} \cdots=$ the experiment mean, $\mathrm{M}_{\mathrm{i}}=$ the main plot treatment effect, $B_{j}=$ replication or block effect, $d_{i j}=$ the main plot error (error a), $S_{k}=$ the subplot treatment effect, (MS)ik = the main plot and subplot treatment interaction effect, $\mathrm{e}_{\mathrm{ijk}}=$ the subplot error (error $\mathrm{b}$ ). $\mathrm{i}=\mathrm{a}$ particular main plot treatment, $\mathrm{j}=\mathrm{a}$ particular block, $\mathrm{k}=$ a particular subplot treatment. Genetic correlation was calculated from the components of variance and covariance for the genotype term using multivariate analysis of variance in Genstat $\left(12^{\text {th }}\right.$ edition). The correlation coefficient and coefficient of determination values were 
based on 37 Genotypes $(n=37)$.

\section{Results and Discussion}

\subsection{Genetic Variability for Drought Tolerance in Cowpea Genotypes}

The results from analysis of variance for chlorophyll content, efficiency of photosystem II, non-photochemical quenching (Table 1), drought recovery, leaf wilting index (LWI) (Table 2), seed yield and its components (Table 3) showed that Genotypes were significantly different, indicating the presence of genetic variation among the cowpea genotypes for these traits that is essential for improvement of the crop for drought tolerance.

Table 1. Mean squares of physiological drought stress indicators of cowpea genotypes at vegetative stage.

\begin{tabular}{ccccc}
\hline Source of variation & df & Chl C & Phi2 & NPQ \\
\hline Replication & 1 & 559.91 & 0.00 & 1.53 \\
water Levels & 1 & 3706.00 & 1.56 & 200.02 \\
Main Plot Error & 1 & 218.59 & 0.07 & 2.08 \\
Genotypes & 36 & $72.12^{* * *}$ & $0.02^{*}$ & $2.60^{*}$ \\
Genotypes $\times$ Water Levels & 36 & 25.27 & $0.02^{*}$ & 2.40 \\
Sub Plot Error & 72 & 26.71 & 0.01 & 1.58 \\
\hline
\end{tabular}

${ }^{*}$, ${ }^{* * *}$ significant at $\mathrm{P} \leq 0.05, \mathrm{P} \leq 0.001$ respectively, df: degrees freedom, ChlC: Chlorophyll content, Phi2: Efficiency of photosystem II, NPQ: Non-photochemical quenching.

Table 2. Mean squares of morphological drought stress indicators at vegetative stage.

\begin{tabular}{ccccc}
\hline Source of variation & df & Recovery & Stem Greenness & Wilting Index \\
\hline Replication & 1 & 0.2 & 5 & 0 \\
Genotypes & 36 & $3.56^{* *}$ & $1.93 \mathrm{~ns}$ & $0.02^{* *}$ \\
Error & 36 & 1.43 & 1.21 & 0.01 \\
\hline
\end{tabular}

** significant at $\mathrm{P} \leq 0.01$, ns: non-significant, df: degrees of freedom.

Table 3. Mean squares of seed yield and its components under drought stress at reproductive stage.

\begin{tabular}{cccccc}
\hline Source of variation & DF & NPP & NSP & 100 SWT (g) & SY (g) \\
\hline Replication & 1 & 2.55 & 4.80 & 9.08 & 4.41 \\
water Levels & 1 & $30.50^{*}$ & 70.53 & 0.68 & 6.08 \\
Main Plot Error & 1 & 0.05 & 6.53 & 3.01 & 1.88 \\
Genotypes & 29 & $7.64^{* * *}$ & $12.20^{* * *}$ & $1.00^{*}$ & $2.59^{* *}$ \\
Genotypes $\times$ Water Levels & 29 & 2.51 & $4.72^{*}$ & $1.18^{* *}$ & 1.28 \\
Sub Plot Error & 58 & 2.22 & 2.74 & 0.51 & 0.90 \\
\hline
\end{tabular}

${ }^{*},{ }^{* *},{ }^{* *}$ significant at $\mathrm{P} \leq 0.05, \mathrm{P} \leq 0.01, \mathrm{P} \leq 0.001$ respectively, $\mathrm{df}=$ degree of freedom, $\mathrm{NPP}=$ Number of pods per plant, NSP = Number of seeds per pod, SWT $=$ Seed weight, $\mathrm{SY}=$ Seed yield, $\mathrm{g}=$ grams . 


\subsection{Physiological and Morphological Response of Cowpea Genotypes to Drought Stress at Vegetative Stage}

Although the interaction between genotypes and water levels when averaged across the two water levels was found to be non-significant, there were detectable differences in the performance of genotypes under drought stress. Drought stress consistently and significantly reduced the efficiency of photosystem II, Chlorophyll content of the tested genotypes (Table 4) though the effect varied in both improved and local genotypes. The reduction in efficiency of photosystem II was supported by an increase in non-photochemical quenching (NPQ) as shown by a strong negative correlation $(\mathrm{r}=-0.76, \mathrm{P} \leq 0.001)$, suggesting that a greater portion of the energy was thermally dissipated (Figure 1 and Table 5). [27] reported that an increase in NPQ protects the plant against photo damage and this reduces the quantum yield of photosystem II. NPQ plays a key role in the protection of PSII from photodamage. NPQ is considered as an indicator of excess excitation energy [28]. The maximum quantum efficiency of photosystem II provides a measure of the rate of linear electron transport, hence, an indication of overall photosynthetic capacity [29].

Genotypes SECOW 4W, SECOW 5T, WC 67B, NE 6 maintained higher levels of chlorophyll content in their leaves similar to drought tolerant checks such as Dan ILA, IT 89KD-288 and IT 93K-452-1 under water stress (Table 4). The average chlorophyll content (SPAD) measurement under no stress and severe

Table 4. Mean of chlorophyll characteristics and drought recovery.

\begin{tabular}{|c|c|c|c|c|c|c|c|}
\hline \multirow[b]{2}{*}{ Genotype } & \multicolumn{3}{|c|}{ No Water Stress } & \multicolumn{4}{|c|}{ Water Stress } \\
\hline & SPAD & Phi2 & NPQ & SPAD & Phi2 & NPQ & Recovery \\
\hline SECOW 4W & 57.32 & 0.56 & 1.02 & 50.87 & 0.49 & 1.43 & 5 \\
\hline SECOW 2W & 54.30 & 0.59 & 1.27 & 46.97 & 0.37 & 5.61 & 3 \\
\hline 182 & 58.17 & 0.63 & 0.92 & 42.58 & 0.28 & 4.01 & 5 \\
\hline SECOW $1 \mathrm{~T}$ & 50.60 & 0.56 & 1.30 & 42.03 & 0.29 & 5.28 & 5 \\
\hline IT 91 & 58.83 & 0.55 & 0.89 & 43.62 & 0.32 & 4.54 & 5 \\
\hline 3306 & 56.45 & 0.59 & 0.87 & 46.33 & 0.28 & 3.34 & 5 \\
\hline SECOW 5T & 53.43 & 0.58 & 0.72 & 51.82 & 0.48 & 1.99 & 5 \\
\hline WC27 & 54.97 & 0.66 & 0.58 & 35.45 & 0.30 & 3.01 & 5 \\
\hline NE 45 & 54.32 & 0.62 & 0.78 & 46.25 & 0.30 & 3.98 & 5 \\
\hline WC64 & 55.22 & 0.68 & 0.65 & 34.77 & 0.30 & 1.59 & 1 \\
\hline SECOW 3B & 53.62 & 0.62 & 0.66 & 48.70 & 0.51 & 2.50 & 5 \\
\hline SECOW 5 X SECOW 1 & 56.25 & 0.62 & 0.48 & 47.03 & 0.42 & 1.83 & 5 \\
\hline NE 20 & 56.17 & 0.59 & 1.01 & 46.77 & 0.37 & 3.35 & 5 \\
\hline NE50 & 58.03 & 0.62 & 0.95 & 43.15 & 0.16 & 5.14 & 3 \\
\hline MU17 & 55.77 & 0.64 & 0.59 & 45.57 & 0.46 & 1.94 & 3 \\
\hline MU15 & 58.20 & 0.65 & 0.71 & 41.50 & 0.39 & 4.48 & 5 \\
\hline
\end{tabular}




\section{Continued}

\begin{tabular}{|c|c|c|c|c|c|c|c|}
\hline WC8 & 46.10 & 0.37 & 0.44 & 41.92 & 0.26 & 4.40 & 3 \\
\hline SECOW 5 X NE39 & 50.17 & 0.57 & 2.18 & 45.23 & 0.33 & 5.83 & 5 \\
\hline NE 44 & 55.13 & 0.63 & 0.77 & 33.27 & 0.26 & 4.57 & 1 \\
\hline WC30 & 55.62 & 0.56 & 1.57 & 48.87 & 0.54 & 1.55 & 5 \\
\hline NE 70 & 54.70 & 0.60 & 0.90 & 42.38 & 0.23 & 3.07 & 1 \\
\hline IT 84 & 56.02 & 0.61 & 0.87 & 45.43 & 0.34 & 4.81 & 5 \\
\hline BRAZIL5 & 57.42 & 0.56 & 0.87 & 34.15 & 0.24 & 4.53 & 1 \\
\hline NE 67 & 56.27 & 0.52 & 1.13 & 40.77 & 0.26 & 5.65 & 3 \\
\hline WC67B & 59.48 & 0.61 & 1.45 & 53.32 & 0.48 & 2.43 & 5 \\
\hline MU 24C & 58.12 & 0.70 & 0.65 & 48.03 & 0.31 & 4.39 & 5 \\
\hline NE 5 & 50.28 & 0.56 & 0.87 & 47.75 & 0.47 & 1.70 & 3 \\
\hline NE30 & 56.47 & 0.54 & 1.03 & 46.97 & 0.36 & 4.90 & 5 \\
\hline WC 17 & 55.20 & 0.58 & 0.88 & 45.28 & 0.48 & 4.12 & 5 \\
\hline NE6 & 56.55 & 0.60 & 0.92 & 52.53 & 0.51 & 1.64 & 3 \\
\hline \multicolumn{8}{|l|}{ Checks } \\
\hline DANILA & 62.22 & 0.51 & 1.31 & 54.95 & 0.65 & 0.78 & 5 \\
\hline IT89KD-288 & 62.28 & 0.61 & 1.11 & 54.52 & 0.46 & 1.98 & 5 \\
\hline IT93K-452-1 & 55.53 & 0.55 & 1.35 & 54.27 & 0.59 & 0.74 & 5 \\
\hline IT96D-610 & 65.93 & 0.58 & 1.08 & 60.63 & 0.60 & 0.86 & 5 \\
\hline IT97K-499-38 & 61.63 & 0.63 & 0.85 & 52.43 & 0.51 & 1.67 & 5 \\
\hline IT97K-819-118 & 57.37 & 0.70 & 0.60 & 41.82 & 0.45 & 3.35 & 5 \\
\hline IT98K-128-3 & 59.65 & 0.59 & 1.01 & 50.55 & 0.31 & 4.30 & 5 \\
\hline Grand Mean & 56.32 & 0.59 & 0.95 & 46.31 & 0.39 & 3.28 & 4.19 \\
\hline $\operatorname{LSD}(5 \%)$ & 7.70 & 0.16 & 0.82 & 12.67 & 0.25 & 3.51 & 2.42 \\
\hline CV\% & 7 & 13 & 42 & 14 & 32 & 53 & 30 \\
\hline
\end{tabular}

Checks: IITA drought tolerant lines were included for screening at vegetative stage, NE \& WC: Local Genotypes, SECOW: Serere released varieties, MU: Makerere breeding lines.

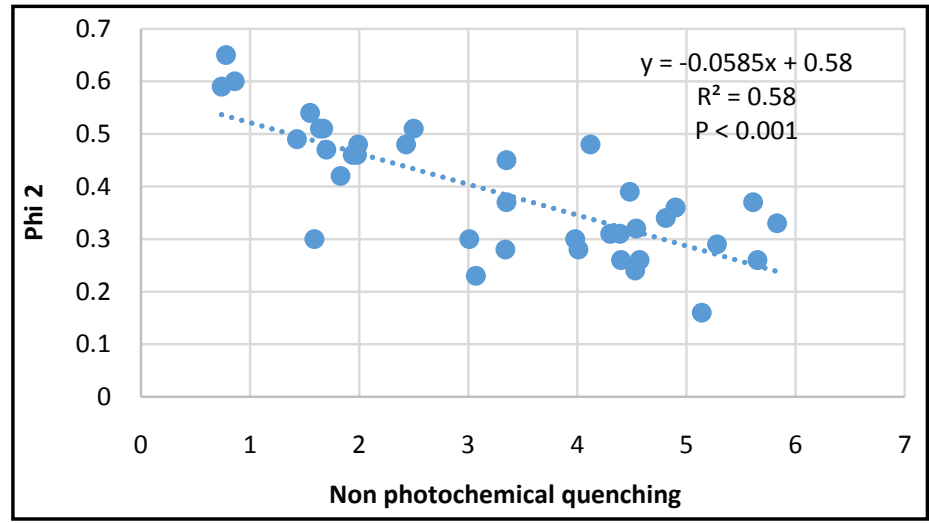

Figure 1. Regression analysis of efficiency of photosystem II and non-photochemical quenching under soil moisture stress. 
Table 5. Correlation analysis between chlorophyll characteristics and drought recovery of cowpea genotypes.

\begin{tabular}{ccccc}
\hline & SPAD & NPQ & Phi2 & Recovery \\
\hline SPAD & 1 & & & \\
NPQ & $-0.55^{* * *}$ & 1 & & \\
Phi2 & $0.75^{* * *}$ & $-0.76^{* * *}$ & 1 & 1 \\
Recovery & $0.56^{* * *}$ & -0.12 & $0.43^{* *}$ & 1 \\
\hline
\end{tabular}

**, *** significant at $\mathrm{P} \leq 0.01, \mathrm{P} \leq 0.001$ respectively.

stress conditions were 56 and 46 respectively (Table 4). Drought stress imposed at the vegetative stage, significantly $(\mathrm{P} \leq 0.05)$ decreased the relative chlorophyll content. The results are consistent with [30]. [31] reported that severe drought stress on wheat significantly decreased the chlorophyll content of the leaves. The decrease in chlorophyll under drought stress is mainly the result of damage to chloroplasts caused by active oxygen species [32]. The predictability of the efficiency of photosystem II from the chlorophyll content (Figure 2) as shown by the coefficient of determination of $56 \%$ indicated a high association between efficiency of photosystem II and chlorophyll content $(r=0.75, \mathrm{P} \leq 0.001)$. Similar findings were reported by [15]. Furthermore, there were strong and moderate significant positive correlation between chlorophyll content with drought recovery and efficiency of photosystem II with drought recovery respectively (Table 5). Suggesting that Genotypes that maintained a higher chlorophyll content and efficiency of photosystem II such as SECOW 4W, SECOW 5T, WC 30, WC 67B had higher chances of recovering from drought. As such Chlorophyll content and Phi2 could be used as reliable and efficient reference indicators in the selection of drought tolerant genotypes. Similar findings were reported by [15]. The low predictability of non-photochemical quenching from chlorophyll content as indicated by the coefficient of determination of $30 \%$ implied a low degree of association between NPQ and chlorophyll content. This could be due to damaged membranes which reduced the mobility of the electron transport chain carriers and reduced proton gradient across thylakoid membrane [33].

Some cowpea genotypes showed high leaf wilting index scores (LWI) after the first week of stress, for example genotypes WC 64 and BRAZIL 5. On the other hand, the following genotypes showed lower wilting index scores during the whole stress period; IT98K-205-8, IT97K-499-38, IT98K-503-1, NE 67, SECOW 1T, SECOW 3B, WC 27, NE 20, IT98K-1283, MU 15, IT 84, 182, IT97K-819-118, DAN ILA. The results were consistent with previous studies in cowpea, which also identified leaf wilting within the first week of water stress [34]. Although some genotypes had higher wilting index scores but they were able to fully recover after rehydration. This was attributed to Type 2 drought tolerance mechanism that most genotypes had [34]. These genotypes derived water from their lower canopies, in order to support apical meristematic growth during water stress. Such genotypes show relatively high values of LWI and yet fully recovered after re-watering [25]. 


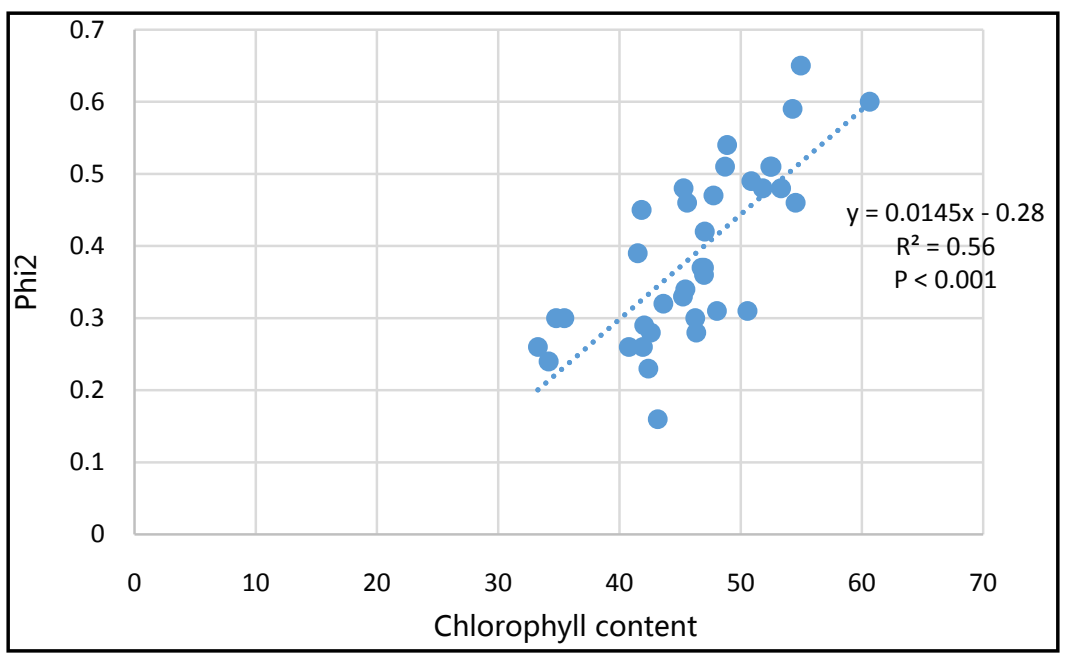

Figure 2. Regression analysis of efficiency of photosystem II and chlorophyll content under soil moisture stress.

Recovery after stress is a process that involves the rearrangement of many metabolic pathways to repair drought-induced damage and to resume plant growth. There was variability in drought recovery among genotypes. Similar findings were reported by [35]. Genotypes that maintained high chlorophyll content under drought stress showed a greater ability to recover from stress. Particularly genotypes SECOW 5T, SECOW 3B, SECOW 4W, WC 67B, NE 6, MU 24C and WC 30 maintained above mean chlorophyll content, efficiency of photosystem II and had a greater ability to recover from stress (Table 5).

\subsection{Yield and Its Components Indicators of Drought Tolerance at Reproductive Stage}

Grain yield under drought is the primary trait for selection in crop improvement programs [1]. Different morphological and physiological characters contribute to grain yield. Therefore, the knowledge of genetic relationship between grain yield and its components can improve the efficiency of selection in breeding programs. The mean seed yield performance of the thirty (30) cowpea genotypes ranged between 2.7 to 6.0 grams/plant under no soil moisture stress and 0.7 to 5.7 grams/plant under soil moisture stress (Table 5). Genotype NE 30 and WC 8 gave the highest seed yield under no stress and stress respectively. Genotype WC 17 produced the highest number of pods both under no soil moisture stress and soil moisture stress conditions while IT 84 produced the highest number of seeds per pod both under no soil moisture stress and soil moisture stress conditions (Table 6). Drought stress reduced the seed yield and its components, but, improved genotypes and landraces responded differently to the stress. Brazil 5, NE 45 and NE 50 experienced a seed yield reduction of $83 \%$ and $36 \%$ respectively under soil moisture stress while WC 8, MU24C, Secow 5T, Secow 3B, MU15, IT84 and Secow 4w gave relatively higher yields. [21] reported that the reduction in seed yield under water stress was associated with the decrease in yield components such as number of pods per plant and number of seeds per pod. Cowpea 
has been reported to be very sensitive to water stress at flowering and pod-filling stages [36]. Drought stress caused flower abortion, pod dropping and reduced seed filling [37]. Therefore, the reduction in number of pods per plant and number of seeds per pod in this study was attributed to abscission of reproductive structures and limitation of dry matter partitioning to reproductive sink. Genotypes that maintain higher yields under drought stress are desirable as such, genotypes SECOW 5T, SECOW 3B, SECOW 4W, WC 8, MU 24C, MU15, and IT 84 were classified as tolerant because they produced above mean yields and had minimal yield reduction under water stress. The presence of a strong positive significant genetic correlation among seed yield, pods per plant and seeds per pod implied that yield gains under drought stress in the tested genotypes could be made by simultaneously selecting for pods per plant and seeds per pod (Table 7).

Table 6. Genotype means for yield and its components.

\begin{tabular}{|c|c|c|c|c|c|c|}
\hline \multirow[b]{2}{*}{ Genotypes } & \multicolumn{2}{|c|}{ Seed yield } & \multicolumn{2}{|c|}{ Number of pods per plant } & \multicolumn{2}{|c|}{ Number of seeds per pod } \\
\hline & no stress & Stressed & no stress & Stressed & no stress & Stressed \\
\hline SECOW 4W & 4.7 & 5.0 & 5.8 & 6.3 & 16.7 & 14.7 \\
\hline SECOW 2W & 4 & 5.3 & 7.5 & 6.8 & 16.3 & 17.7 \\
\hline 182 & 2.7 & 2.7 & 4.3 & 6.5 & 10.7 & 13.3 \\
\hline SECOW 1T & 5.3 & 4.3 & 5.2 & 5.5 & 15 & 19.7 \\
\hline IT 91 & 3.7 & 3.7 & 4 & 2.3 & 16 & 16.0 \\
\hline 3306 & 2.7 & 3.0 & 6.5 & 4.8 & 15.3 & 13.7 \\
\hline SECOW 5T & 4.3 & 5.3 & 5.2 & 6.2 & 15 & 17.3 \\
\hline WC27 & 4.7 & 4.0 & 6.7 & 7.5 & 15.3 & 15.3 \\
\hline NE 45 & 3.7 & 2.3 & 5.7 & 3.5 & 16.3 & 17.0 \\
\hline WC64 & 5.3 & 4.0 & 8.5 & 8.8 & 16.7 & 19.3 \\
\hline SECOW 3B & 4.3 & 5.3 & 6.8 & 7.8 & 15 & 14.0 \\
\hline SECOW 5X SECOW 1 & 3.7 & 2.7 & 4 & 3.3 & 16.7 & 13.3 \\
\hline NE 20 & 5.7 & 4.7 & 6.7 & 7.8 & 14 & 16.7 \\
\hline NE50 & 4.7 & 3.0 & 3.7 & 4.3 & 16 & 17.7 \\
\hline MU17 & 5 & 4.7 & 6 & 6.8 & 16.7 & 16.0 \\
\hline MU15 & 4.3 & 5.3 & 4.8 & 4.7 & 14.3 & 15.7 \\
\hline WC8 & 5.7 & 5.7 & 7.2 & 6.8 & 16.7 & 14.7 \\
\hline SECOW 5 X NE 39 & 3.3 & 3.3 & 6.5 & 6.8 & 14.7 & 13.3 \\
\hline NE 44 & 4.3 & 5.0 & 8.2 & 8.5 & 14.3 & 15.3 \\
\hline WC30 & 5 & 3.7 & 6.2 & 3.0 & 16.3 & 15.3 \\
\hline NE 70 & 5.3 & 4.3 & 9.3 & 9.2 & 13.3 & 19.7 \\
\hline IT 84 & 4.3 & 5.0 & 3.7 & 4.5 & 19.7 & 17.0 \\
\hline BRAZIL5 & 4 & 0.7 & 5 & 4.3 & 11.7 & 9.7 \\
\hline
\end{tabular}


Continued

\begin{tabular}{ccccccc}
\hline NE 67 & 5 & 4.0 & 6.2 & 4.0 & 19 & 15.7 \\
WC67B & 5 & 3.3 & 6.5 & 4.8 & 14.7 & 16.0 \\
MU 24C & 4 & 5.0 & 6.8 & 4.8 & 15.7 & 12.0 \\
NE 5 & 4 & 4.7 & 6.5 & 5.0 & 18 & 16.7 \\
NE30 & 6 & 5.0 & 7 & 6.3 & 17 & 17.0 \\
WC 17 & 5 & 3.3 & 6.3 & 5.3 & 17.3 & 20.3 \\
NE6 & 3.3 & 2.3 & 4.5 & 2.8 & 8.7 & 13.3 \\
MEAN & 4.4 & 4.0 & 6.0 & 5.7 & 15.4 & 15.8 \\
LSD (5\%) & 0.70 & 0.70 & 1.18 & 1.18 & 2.09 & 2.09 \\
CV (\%) & 19.23 & 29.27 & 23.32 & 32.55 & 14.58 & 15.15 \\
\hline
\end{tabular}

$\mathrm{NPP}=$ Number of pods per plant, NSP = Number of seeds per pod, SWT $=$ Seed weight in grams, GY = Grain yield in grams, NE \& WC: Landraces, SECOW: Serere released varieties, MU: Makerere breeding lines.

Table 7. Genetic correlation among seed yield, number of pods per plant and number of seeds per pod under intermediate stress of 30 cowpea genotypes.

\begin{tabular}{|c|c|c|}
\hline & Number of pods per plant & Number of seeds per pod \\
\hline Seed Yield & $0.57^{* *}$ & $0.66^{* * *}$ \\
\hline
\end{tabular}

\section{Conclusion}

Considerable variability was observed in morphological, physiological and yield related indicators among the tested cowpea genotypes under drought stress and no stress conditions. Mean yield under stress and non-stress, maintenance of above average chlorophyll content and efficiency of photosystem II, their ability to quickly recover from stress were useful in identifying drought tolerant genotypes. However, the use of wilting scores alone to identify drought tolerant genotypes was not conclusive. Genotypes SECOW 5T, SECOW 3B, SECOW 4W, WC 30 and MU $24 \mathrm{C}$ were recommended as sources of drought tolerance and can be utilized as parents for breeding programs.

\section{Acknowledgements}

This work was funded by the Inter-University Cooperation to Train Crop Scientists for Enhancing Agriculture in Africa (CSAA) (INTRA-ACP-CSAA) Project. Additional support was provided through an Alliance for a Green Revolution in Africa (AGRA) grant to the Makerere University Cowpea Breeding Program and Regional Universities Forum for Capacity Building in Agriculture (RUFORUM).

\section{References}

[1] Agbicodo, E.M., Fatokun, C.A., Muranaka, S., Visser, R.G.F. and Linden van der, C.G. (2009) Breeding Drought Tolerant Cowpea: Constraints, Accomplishments, and Future Prospects. Euphytica, 167, 353-370. 
https://doi.org/10.1007/s10681-009-9893-8

[2] Sariah, J. (2010) Enhancing Cowpea (Vigna unguiculata L.) Production through Insect Pest Resistant Line in East Africa. PhD Thesis, University of Copenhagen, Copenhagen.

[3] Orawu, M., Obuo, J. and Omadi, R. (2015) Distribution and Detection of Cowpea Viruses Infecting Cowpea in Uganda. American Journal of Plant Science, 6, 574581. https://doi.org/10.4236/ajps.2015.65062

[4] Adipala, E. (1994) Cowpea Improvement in Uganda: Current Status of Diseases and Pest Management Half Year Report for the Period September 1993-March 1994. Makerere University, Kampala.

[5] Rusoke, D.G. and Rubaihayo, P. (1994) The Influence of Some Crop Protection Management Practices on Yield Stability of Cowpeas. African Journal of Crop Science, 2, 143-148.

[6] Bisikwa, J. (2011) McKnight Foundation Collaborative Crops Research Project No. 09-480 Improving Food Security through Participatory Development of High Yielding and Pests Resistant Cowpea Varieties in Uganda Annual Progress Report-Narrative.

[7] Hall, A.E. (2012) Phenotyping Cowpea for Adaptation to Drought. Frontiers in Physiology, 3, 1-8. https://doi.org/10.3389/fphys.2012.00155

[8] Bernstein, L., Bosch, O., Canziani, Z., Chen, R. and Davidson, C.O. (2008) Climate Change 2007: Synthesis Report: An Assessment of the Intergovernmental Panel on Climate Change. Intergovernmental Panel on Climate Change, Geneva.

[9] Alidu, M., Atokple, I. and Akromah, R. (2013) Genetic Analysis of Vegetative Stage Drought Tolerance in Cowpea. Greener Journal of Agricultural Sciences, 3, 481496.

[10] Boyer, J.S. and McPherson, H.G. (1975) Physiology of Water Deficits in Cereal Crops. Advances in Agronomy, 27, 1-27. https://doi.org/10.1016/S0065-2113(08)70006-3

[11] Wang, Z.L. and Huang, B.R. (2004) Physiological Recovery of Kentucky Bluegrass from Simultaneous Drought and Heat Stress. Crop Science, 44, 1729-1736. https://doi.org/10.2135/cropsci2004.1729

[12] Nkouannessi, M. (2005) The Genetic, Morphological and Physiological Evaluation of African Cowpea Genotypes. MSc Thesis, University of the Free State, Bloemfontein.

[13] Hamidou, F., Zombre, G. and Braconnier, S. (2007) Physiological and Biochemical Responses of Cowpea Genotypes to Water Stress under Glasshouse and Field Conditions. Journal of Agronomy and Crop Science, 193, 229-237. https://doi.org/10.1111/j.1439-037X.2007.00253.X

[14] Anantharaju, P. and Muthiah, A.R. (2008) Screening for Drought Tolerance in Cowpea. Legume Research, 31, 283-285.

[15] Hayatu, M. and Mukhtar, F.B. (2010) Physiological Responses of Some Drought Resistant Cowpea Genotypes to Water Stress. Bayero Journal of Pure and Applied Sciences, 3, 69-75.

[16] Mashilo, J. (2013) Response of Dual-Purpose Landraces to Water Stress. MSc Thesis, University of Kwazulu Natal, Durban.

[17] Khaki, N. (2014) Evaluation of Malawi Pigeon Pea (Cajanus Cajan L) Accessions for Tolerance to Moisture Stress and Superior Agronomic Traits in Uganda. MSc Thesis, Makerere University, Kampala.

[18] Bisikwa, J., Ekere, W., Kawooya, R., Biruma, M. and Okello, D. (2014) Farmers 
Guide to Sustainable Cowpea Production in Uganda.

[19] Muchero, W., Roberts, P.A., Diop, N.N., Drabo, I., Cisse, N., Close, T.J., Muranaka, S., Boukar, O. and Ehlers, J.D. (2013) Genetic Architecture of Delayed Senescence, Biomass, and Grain Yield under Drought Stress in Cowpea. PLoS ONE, 8, e70041. https://doi.org/10.1371/journal.pone.0070041

[20] Chiulele, R.M. (2010) Breeding Cowpea for Improved Drought Tolerance in Mozambique. PhD Thesis, University of Kwazulu Natal, Durban.

[21] Gwathmey, C.O. and Hall, A.E. (1992) Adaptation to Midseason Drought of Cowpea Genotypes with Contrasting Senescence Traits. Crop Science, 32, 773-778. https://doi.org/10.2135/cropsci1992.0011183X003200030039x

[22] Muchero, W., Ehlers, J.D. and Roberts, P.A. (2008) Seedling Stage Drought Induced Phenotypes and Drought Responsive Genes in Diverse Cowpea Genotypes. Crop Science, 48, 541. https://doi.org/10.2135/cropsci2007.07.0397

[23] International Board for Plant Genetic Resources (IBPGR) (1983) Cowpea Descriptors. Rome.

[24] Mai-Kodomi, Y., Singh, B.B., Myers, O., Yopp, J.H., Gibson, P.J. and Terao, T. (1999) Two Mechanisms of Drought Tolerance in Cowpea. Indian Journal of Genetics \& Plant Breeding, 59, 309-316.

[25] Pungulani, L.L.M., Milner, J.P., Warren, M.W. and Banda, M. (2013) Improvement of Leaf Wilting Scoring System in Cowpea: From Qualitative Scale to Quantitative Index. Australian Journal of Crop Science, 7, 1262-1269.

[26] Kuhlgert, S., Austic, G., Zegarac, R., Bonsu, I.O., Hoh, D., Chilvers, M.I., Roth, M.G., TerAvest, D. and Kramer, D.M. (2016) MultispeQ Beta: A Tool for Large Scale Plant Phenotyping Connected to the Open PhotosynQ Network. Royal Society Open Science, 3, Article ID: 160592. https://doi.org/10.1098/rsos.160592

[27] Krause, G.H. and Weis, E. (1991) Chlorophyll Fluorescence and Photosynthesis: The Basis. Annual Review of Plant Physiology and Plant Molecular Biology, 42, 313-349.

[28] Parida, A.K., Dagaonkar, V.S. and Phalak, M.S. (2007) Alterations in Photosynthetic Pigments, Protein and Osmotic Components in Cotton Genotypes Subjected to Short-Term Drought Stress Followed by Recovery. Plant Biotechnology Reports, 1, 37-48. https://doi.org/10.1007/s11816-006-0004-1

[29] Balouchi, H.R. (2010) Screening Wheat Parents of Mapping Population for Heat and Drought Tolerance, Detection of Wheat Genetic Variation. World Academy of Science, Engineering \& Technology, No. 42, 210.

[30] Nyachiro, J.M., Briggs, K.G., Hoddinott, J. and Johnson-Flanagan, A.M. (2001) Chlorophyll Content, Chlorophyll Fluorescence and Water Deficit in Spring Wheat. Cereal Research Communications, 29, 135-142.

[31] Fotovat, R., Valizadeh, M. and Toorehi, M. (2007) Association between Water-Use Efficiency Components and Total Chlorophyll Content (SPAD) in Wheat (Triticum aestivum L.) under Well-Watered and Drought Stress Conditions. Journal of Food, Agriculture and Environment, 5, 225-227.

[32] Smirnoff, N. (1995) Antioxidant Systems and Plant Response to the Environment. In: Smirnoff, V., Ed., Environment and Plant Metabolism: Flexibility and Acclimation, BIOS Scientific Publishers, Oxford, 217-243.

[33] Kaiser, W.M. (1987) Effects of Water Deficit on Photosynthetic Capacity. Physiologia Plantarum, 71, 142-149. https://doi.org/10.1111/j.1399-3054.1987.tb04631.x

[34] Pungulani, L.L.M. (2014) Exploring the Genetic Potential of Locally Adapted Germplasm for Drought Tolerance: A Case for Cowpea (Vigna unguiculata (L.)) Walp) 
from Malawi. PhD Thesis, Massey University, Palmerston North.

[35] Anyia, A.O. and Herzog, H. (2004) Genotypic Variability in Drought Performance and Recovery in Cowpea under Controlled Environment. Journal of Agronomy and Crop Science, 190, 151-159. https://doi.org/10.1111/j.1439-037X.2004.00096.x

[36] Turk, K.J. and Hall, A.E. (1980) Drought Adaptation of Cowpea. II. Influence of Drought on Plant Water Status and Relation with Seed Yield. Agronomy Journal, 72, 421-427. https://doi.org/10.2134/agronj1980.00021962007200030005x

[37] Masaya, P. (1991) Adaptation to Photoperiod and Temperature. In: Breeding for Drought Tolerance by Integrative Design: The Case of Common Bean in Ethiopia. PhD Thesis, 445-500.

Submit or recommend next manuscript to SCIRP and we will provide best service for you:

Accepting pre-submission inquiries through Email, Facebook, LinkedIn, Twitter, etc. A wide selection of journals (inclusive of 9 subjects, more than 200 journals)

Providing 24-hour high-quality service

User-friendly online submission system

Fair and swift peer-review system

Efficient typesetting and proofreading procedure

Display of the result of downloads and visits, as well as the number of cited articles Maximum dissemination of your research work

Submit your manuscript at: http://papersubmission.scirp.org/

Or contact ajps@scirp.org 